\section{Historia koszar kawaleryjskich przy Łazienkach Warszawskich w latach 1918-1945}

WERONIKA CHRÓSNY

WOJEWÓDZKI URZAD OCHRONY ZABYTKÓW

W WARSZAWIE

W warszawskim garnizonie w ciągu prawie 30o-letniej historii mieściło się wiele obiektów wojskowych, w tym ponad dwadzieśc różnego rodzaju skupisk koszar, które służyły kwaterunkowi oddziałów stacjonują cych w stolicy. Jednym z takich zespołów były trzy założenia koszar kawaleryjskich, wybudowanych w okolicy Łazienek

Warszawskich najprawdopodobniej z rozkazu wielkiego księcia Konstan kazu wiel zamieszkiwat w pebliskim Belwedere. Książę chciał mieć w poblizu wierne sobi jednostki kawalerii. Pierwsze z koszar kirasjerskie - wybudowano i oddano do użytku ok. 1820 r. Prace przy kolejnym założeniu - koszarach ułańskich - trwały od ok. 1821 do 1825 r. Ostatnie - koszary huza skie - wybudowano i wykończono jeszcze przed wybuchem Powstania Listopadowego w roku 1830 (il 1). Architektem odpowiedzialnym za rozplanowanie oraz szate architektoniczną był Wilhelm Henryk Minter. Większość z zabudowań była drewniana, a wystawiono tylko dwa murowane pawilony służące za magazyny

S.T. Jaroszewski, A. Rottermund, Jakub Hempel, Fryderyk Albert Lessel, Henryk Ittar, Wilhelm Minter. a także okazalszy dom i stajnię dla dowódcy Lejbgwardii Ułanów. Do roku 1914 w koszarach stacjonowały carskie pułki kawalerii. Sukcesywnie wymieniano też dawną zabudowę na nowe, murowane koszary. $\mathrm{W}$ czasie I wojny światowej na swoje potrzeby budynki przejęło wojsko niemieckie, prowadząc zarazem inwentaryzację istniejących budowli. W roku 1918 koszary przejęło Wojsko Polskie.

W czasie kwerendy archiwalnej nie zostały odnalezione dokumenty, które by pokazywały, w jakim stanie znajdowały się poszary kaw weryjsie przy tazienkach po nia większości wojskowej bazy kwaterunkowej na terenie Rzeczpospolitej był bardz zły. Wskutek walk duża część budynków funduszy i remontów przez cztery wojenne lata pogarszał sytuację zabudowań. Dodatkowo należy zauważyć ważny fakt, że młode państwo polskie, uwikłane w obronę granic na wschodzie, nie mogło wydatkować odpowiedniej ilości funduszy na potrzebne prace remontowe, a rotacje oddziałów stacjonujących w koszarach, darza, nie pozwalały na utrzymywanie budynków w należytym stanie. Pomiędzy rokiem 1918 a 1921 prace budowlane

w koszarach były nakierowane na doraźne zaspokojenie potrzeb kwaterujących I wojnie światowej. Ogolny stan zachowabyła mniej lub bardziej zniszczona, a brak tj. brak jednego, odpowiedzialnego gospo-

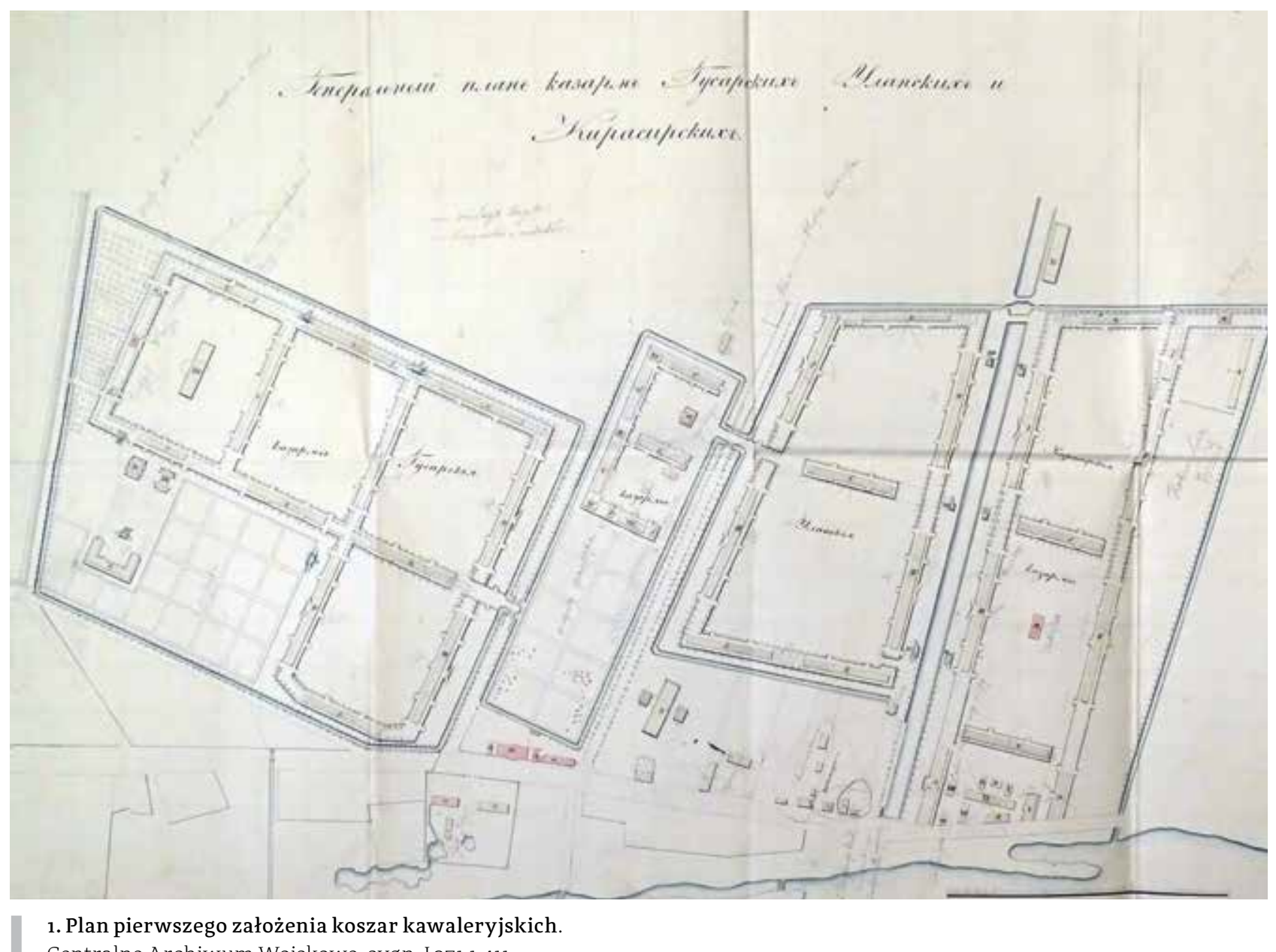

1. Plan pierwszego założenia koszar kawaleryjskich.

oddziałów w najbardziej niezbędnym zakresie i tylko tam, gdzie pozwalały na to działania wojenne. Ponadto rozpoczęto pierwsze prace inwentaryzacyjne budowli pierwsze prace inwentaryzacyjne budow
wojskowych' ${ }^{2}$. Intensyfikacja remontów wojskowych². Intensyfikacja remontów
i budów nastąpiła dopiero po 1921 r., kiedy i budów nastąpiła dopiero po 1921 r., kiedy
to w Polsce ustabilizowała się sytuacja woto w Polsce ustabilizowała się sytuacja wona stałe kwaterować poszczególne oddziały. Zważywszy na powyższą sytuację, można przyjąć, że podobny los spotkał koszary kawalerii przy Łazienkach - najpewniej nie prowadzono w nich żadnych konkretnych prac, a do zachowanych archiwaliów z tego prac, a do zachowanych archiwaliów najwcześniejszego okresu istnienia II
Rzeczypospolitej można zaliczyć jedynie rzut inwentaryzacyjny budynku

A. Król, Budownictwo Wojskowe 1918-1935, t. 1, Warszawa 1936, s. 147. kinematografu's, rzut i przekroje drewnianego budynku mieszkalnego $\mathrm{nr} 71^{4} \mathrm{oraz}$ budynku nr 6o, mieszczącego kuźnię, wszystkie znajdujące się na terenie koszar

huzarskich, a także inwentaryzację przykoszarowych placów ćwiczeń6. Ponadto wszystkie budynki na terenie całego kompleksu koszar zyskały nową numerację. Wspomniane dokumenty wskazują nam jedynie, jakie jednostki stacjonowały w koszarach w tym okresie, a były to:

Centralne Archiwum Wojskowe (dalej cyt. CAW), sygn. L.371.1.342. Byle hoszary Huzarshie Kinematograf B Bd. nr 59.

4 CAW, sygn. I.371.1.342, Budynek drewniany nr 71 wb. koszarach Huzarskich w Łazienkach. CAW, sygn. I. 371.1 .342$, Koszary Eazien
w Warszawie. Budynek nr 60 (kuźnia). 6 CAW, sygn. I.371.1.410, Szkic z pomiarem placu ćwiczeñ izbiórek dla 1 Dyonu Art. Kon. Eazienki; Plan placu Ćwiczeń wI Szwadronie Zapasowego Taboru; Szkic 
1 Dywizjon Artylerii Konnej, szwadron zapasowy 1 Pułku Szwoleżerów oraz

Szwadron Zapasowy Taborów, przy czym należy zauważyć, że były to jednostki tyłowe, które uzupełnień do swoich macierzystych oddziałów walczących na froncie. $\mathrm{W}$ tym miejscu warto również odnotować, że pod względem ewidencyjnym i wyszkoleniowym do Szwadronu Zapasowego I Pułku Szwoleżerów był przypisany Szwadron Przyboczny Naczelnego Wodza

Naczelnika Państwa, czyli oddział którei go zadaniem bya ochro państwa, a poźniej prezydenta, oraz pełnie funkcji reprezentacyjnych. Szwadron Przyboczny stacjonowat w koszarach huzarskich aż do 1926 r., kiedy to został wcielony w strukturę 1 Pułku Szwoleżerów jako 2 Szwadron$^{7}$ (il. 2).

Po zakończeniu działań wojennych, w maju 1921 r. do Warszawy przybył na stałe 1 Pułk Szwoleżerów Józefa Piłsudskiego. Pierwszym pokojowym garnizonem pulk Dy był Cheh, a poszczegolne szwadrony mowane były również we Włodawie

Hrubieszowie ${ }^{8}$. Zważywszy na to, że kad pułku była scisle związana z Piłsudskim, a i sam Marszałek był szefem honorowym pułku, zakwaterowanie szwoleżerów

w stolicy było swoistym wyróżnieniem, ale mogło mieć również przyczynki polityczne, gdyż jak pokazała historia pięć lat później, w czasie przewrotu majowego pułk wierni stanął po stronie swojego szefa.

Szwadrony pułku zajęły cały kompleks koszar ułańskich po obydwu stronach Agrykoli, przemianowanej pózniej na Szwoleżerów. W tym samym rok

7 Wielka Księga Kawalerii Polskiej, t. 46: Szwadrony Przyboczne 1919-1926, red. K. Mijakowski, P. Rożdżestwieński, Warszawa 2012, s. 20-23.

8 Wielka Księga Kawalerii Polskiej, t. 1:1 Putk Szwoleżerów, red. K. Mijakowski, P. Rożdżestwieński, Warszawa rozpoczęły się pierwsze prace budowlane w kompleksie tutejszych koszar. Dawny budynek oficerski nr 49 stojajcy na tere zar huzarskich zyskał nowy numer - 50 . Został on równiez przejęty na rzecz Szkoly Clównej stabu Genz lo zczym plawa remonti wawk

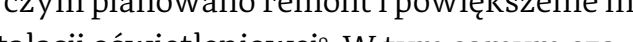
stalacji oświetleniowej. W tym samym czasie planowano kolejny remont oświetlenia w budynku nr 59, tj. dawnym kinematografie, który według zachowanego projektu pełnił również funkcję laboratorium chemicznego $0^{10}$

$$
\text { W roku } 1923 \text { do garnizonu warszaw- }
$$
ednostka - 1 Dywizion Artylerii jednej, huzarskich. Wczé́niej dywizjonstacjoch wat w Górze Kalwari, w dawnych koszarach artylerii ${ }^{11}$

W rok po przybyciu do stolicy konnych artylerzystów w koszarach huzarskich dokonano remontu głównego budynku koszarowego nr 123, w którym kwaterował Szwadron Przyboczny Prezydenta Rzeczypospolitej (il s) Autorem przebudowy był wybitny architekt

Kazimierz Tołłoczko, a sam remont miał na celu nie tylko poprawę warunków, ale również znaczącą zmianę szaty architektonicznej - eklektyczną surowość czerwonych, ceglanych elewacji zastąpiono modernistyczną prostotą poprzez rezygnację z detalu architektonicznego oraz jasność bijąca ze ścian, a sam architekt pisał o tym w ten sposób: W miejsce szablonowej architektury ceglanej, rażącej niemile oko, powstają

9 CAW, sygn. I.371.1.1342, Projekt remontu i powiększenia urzadzzenia óświetlenia elektrycznego w bud. nr 50 Szkołę Sztabu Generalnego dla oficerów.

10 CAW, sygn I. 371.1.342. Koszary Eazienhowshie

w Warszawie. Budynek nr 59. Projekt urzadzenia oświetlenia elektrycznego i przetwornicy w Laboratorium Chemicznem.

P. Zarzycki, Zarys historii wojennej pułków Polski w Kampanii Wrześniowej. 1 Dywizjon Artylerii Konnej,

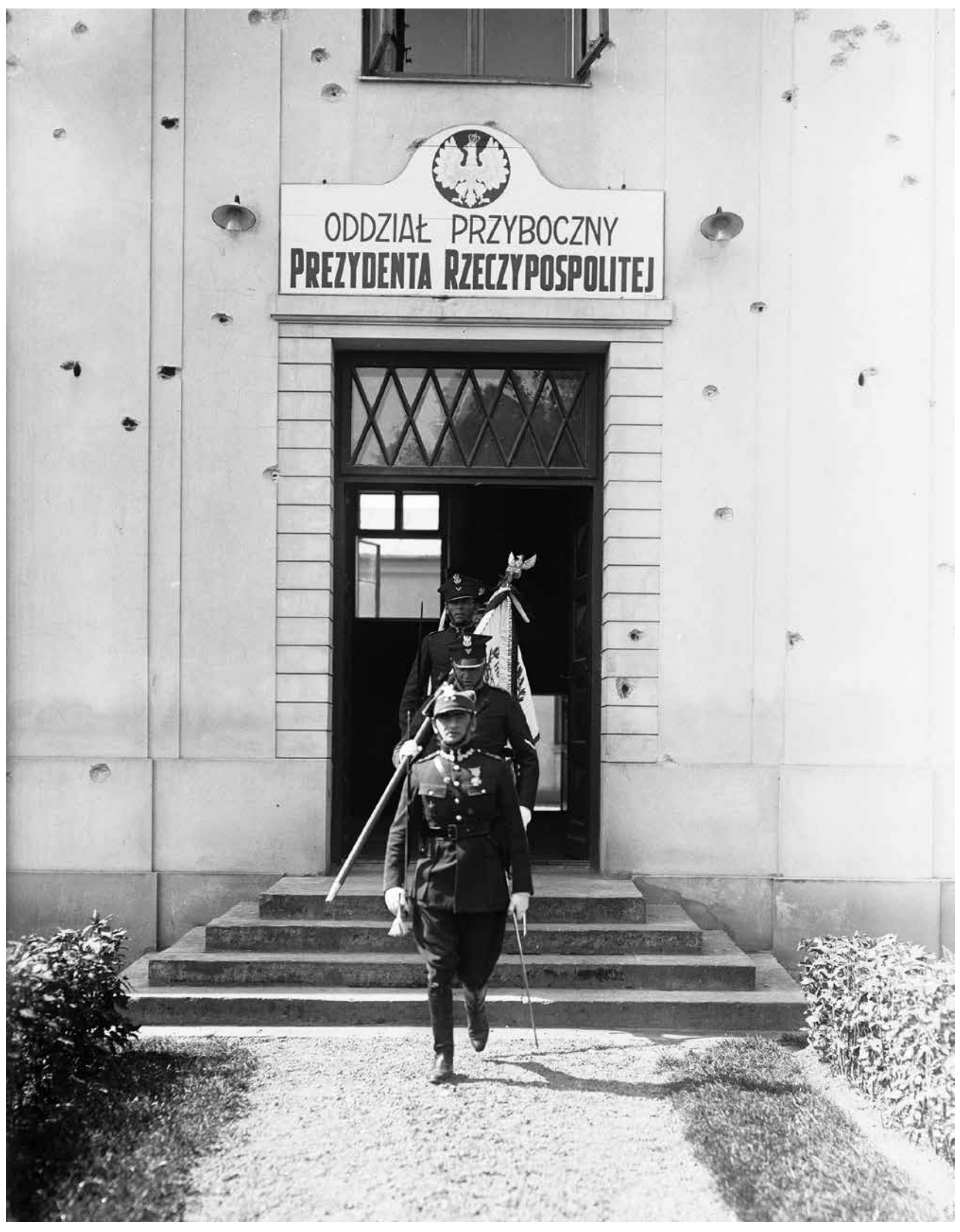

2. Wyprowadzenie sztandaru Oddziału Przybocznego Prezydenta Rzeczypospolitej z budynk zajmowanego przez oddział, 7 VII 1926. Na odnowionej elewacji widac slady kul - pozostałošc

po zakończonym przewrocie majowym i walkach z sąsiadującym 1 Pułkiem Szwoleżerów. Narodowe 


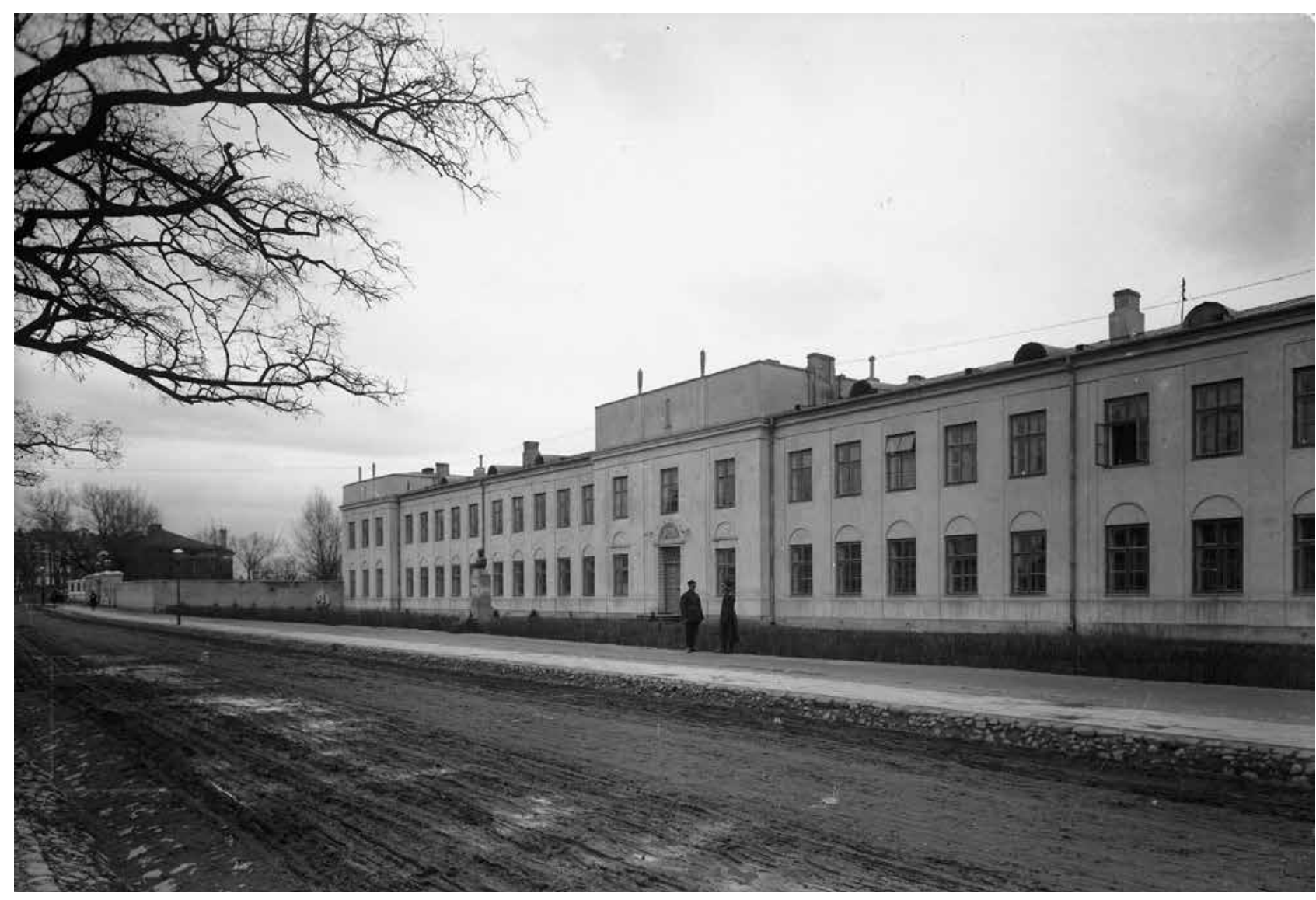

3. Przebudowany według projektu architekta Tołłoczki budynek nr 50

budynki o wyrazie bardzo pogodnym, pociągającym dla żołnierza, który w służbie wojskowej nie powinien widzieć ciężkiej, koniecznej do przebycia pańszczyzny, lecz szkołe przygotowania do ewentualnej szkołę przygotowania do ewentualnej obrony kraju ${ }^{1{ }^{\prime 2}}$. Równiez w pierwszej połowie lat 20. XX w. w budynkach nr 6 i 36 terenie koszar huzarskich prowadzono prace związane ze wstawianiem nowy okien i parapetów. Prace prowadziło Przedsiębiorstwo Remontowo-Budowlane Bolesław Mierzejewski ${ }^{13}$

W roku 1926 okolice parku

Łazienkowskiego, Belwederu i koszar kawalerii były niemymi świadkami walk przewrotu majowego. Koszary szwoleżerów,

12 K. Tołłoczko, Domy profesorów Uniwersytetu przy ulicy Brzozowej i koszary Oddziału Przybocznego Prezydenta Rzeczypospolitej przy ulicy Huzarskie, "Architektura i Bulownictwo 1925, 2. 3, s. 20 . 13 CAW, sygn. 1.371 .1 .323$, Rysunki wykonawcze robót
w1 1.a.k. Bud. 6. 50, 36, 39, 26 . czyli oddziału wiernego Marszałkowi, były swoistą „wyspą" w południowej części miasta, która opanowana była przez wojska rządowe. W związku z tym podjęto działania, które miały skutkować zdobyciem koszart Jak pisatw swoich wsponnie szpor. Joze willayn Przybocznego Prezydenta Rzeczypospolitej, 13 maja otrzymał telefoniczny rozkaz obrony koszar huzarskich, w których kwaterowały oddziały wierne rządowi. Podporucznik zablokował wszystkie bramy wjazdowe, partery budynków obsadził swoimi ludźmi uzbrojonymi w granaty oraz karabinki, a na piętrach umieścił ręczne karabiny maszynowe oraz dwa cięzie karabiny maszynowe Po pozdni jego stanowiskazaczęa we.Po poly niu jego stanowisk azaçła ostrzeliwac mieszana grupka zlożona $z$ wojsię ckm-y rozmieszczone na terenie koszar 14 A. Czubińnki, Przewrót majowy 1926, Warszawa 1989, s. 178-183. ppor. Jozzef wilczyíski, oficer Szwadronu skowychicywilów, do ktorych dołączyły

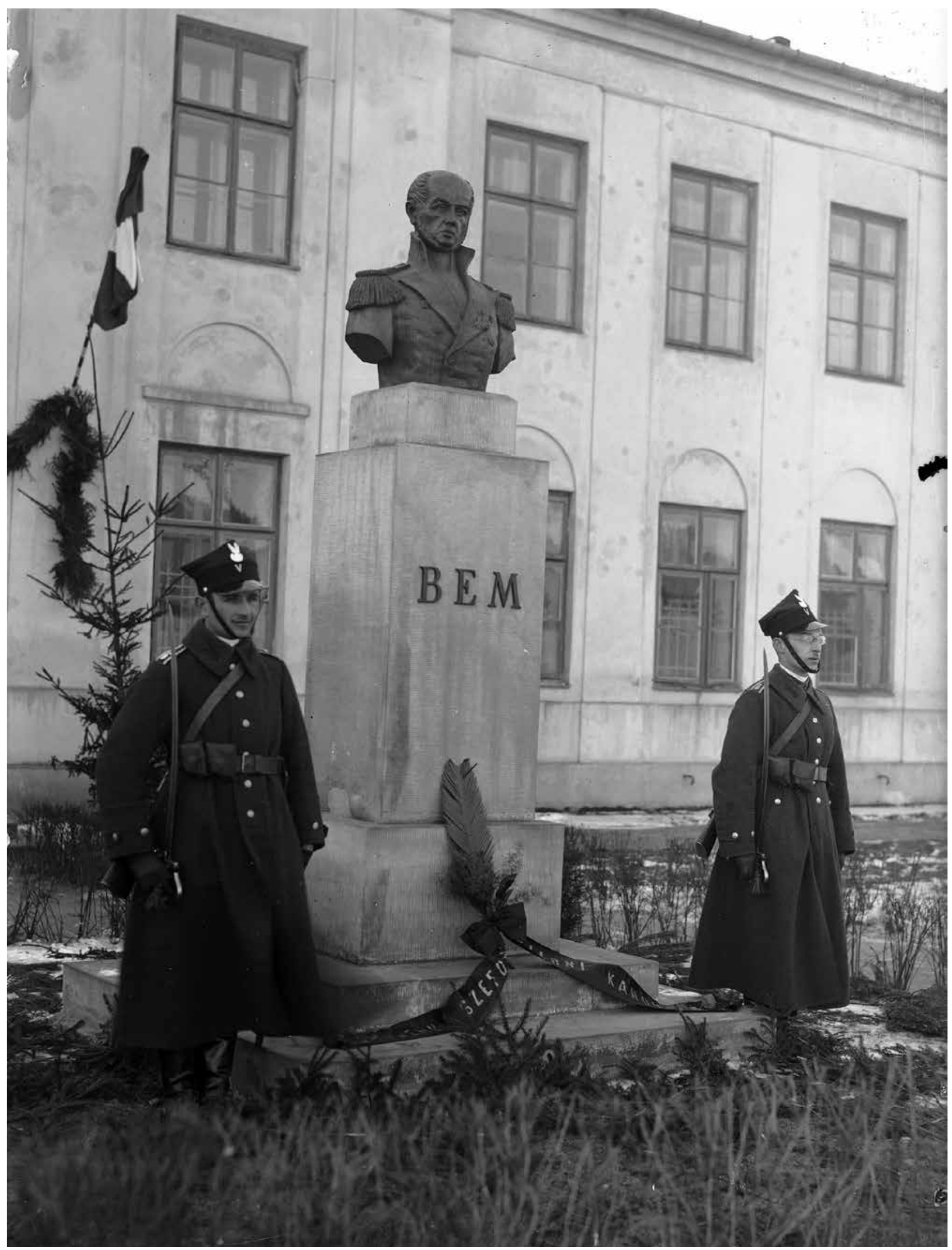

4. Warta honorowa 1 Dywizjonu Artylerii Konnej przed pomnikiem gen. Bema przy ul. Huzarskiej, 1928 r. Narodowe Archiwum Cyfrowe, sygn. 107-172-7 


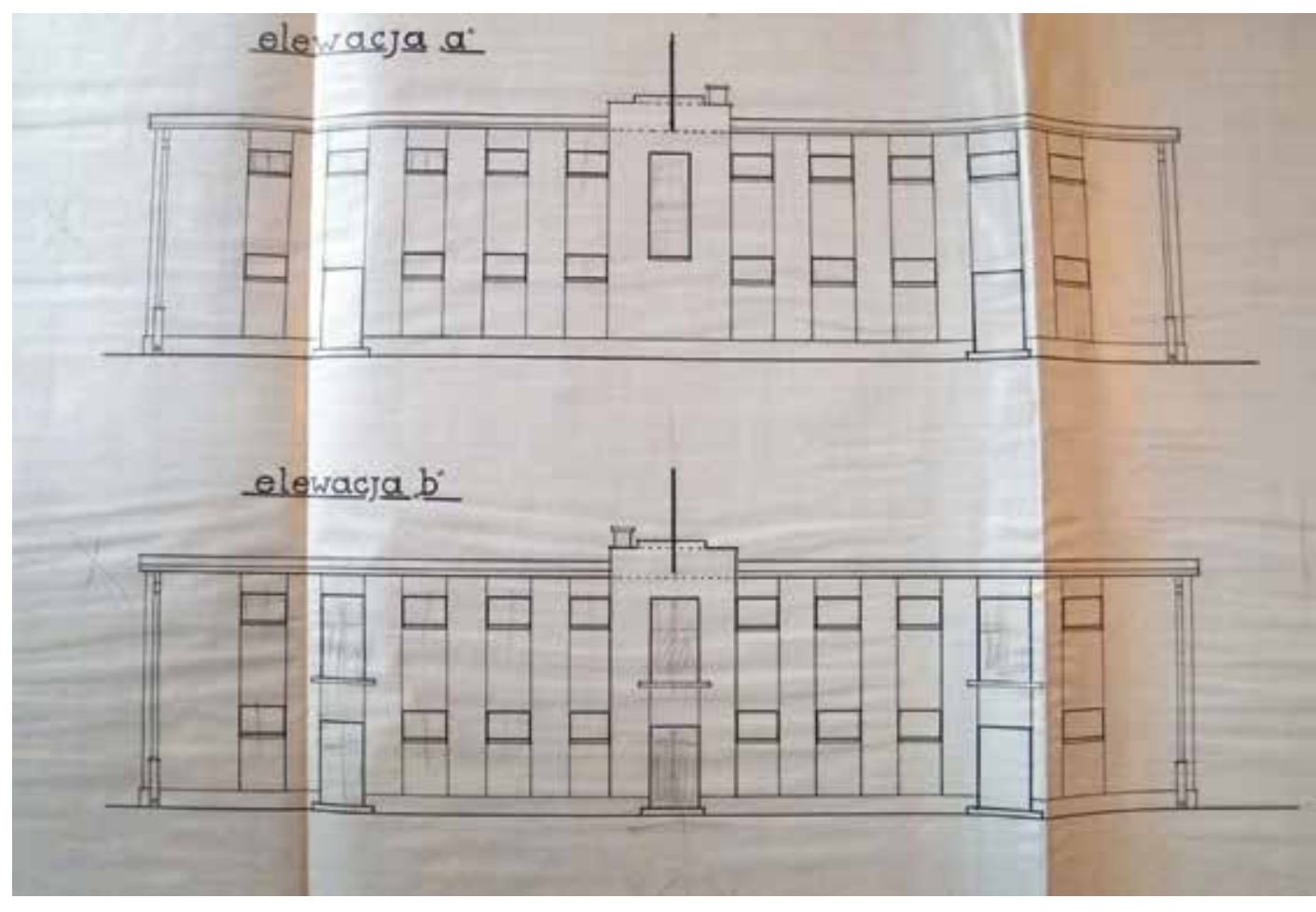

5. Rysunki elewacji na projekcie magazynu MOB dla 1 Pułku

Szwoleżerów. Centralne Archiwum Wojskowe, sygn. I.371.1.34

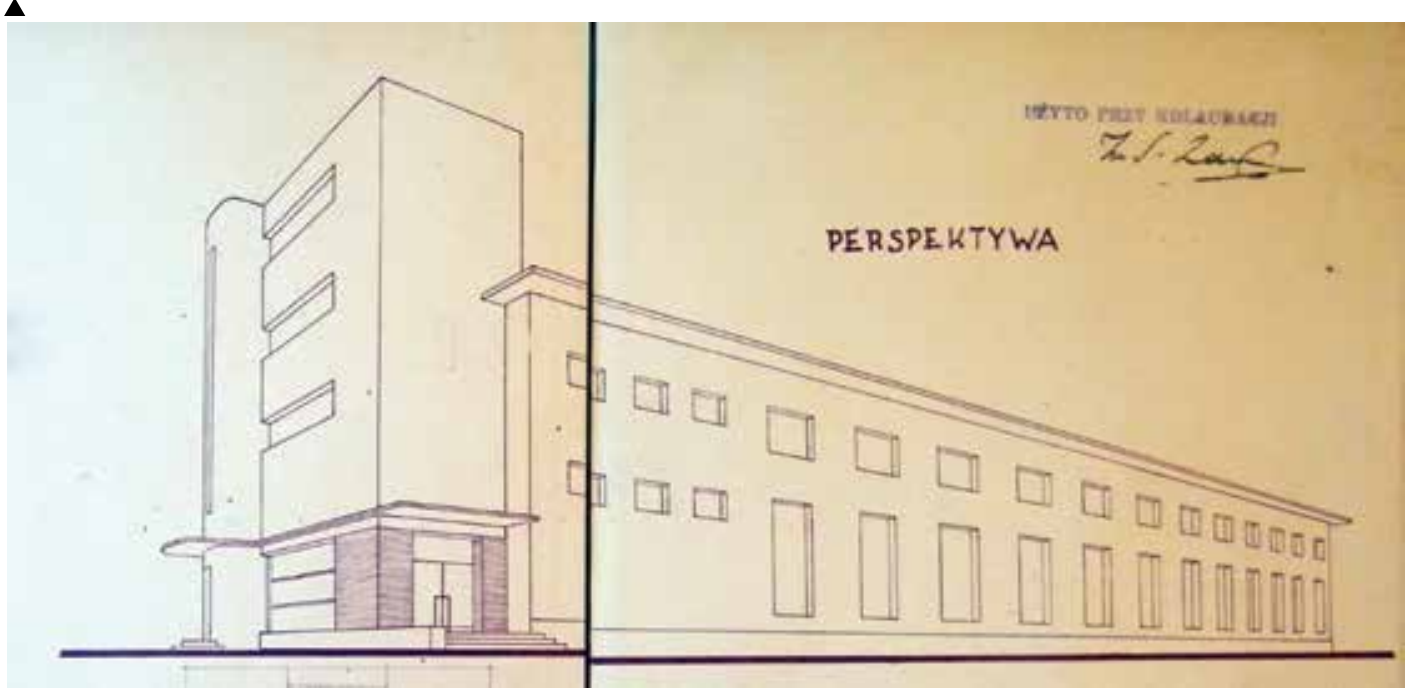

6. Rysunek dawnej kuchni żołnierskiej nr 80 w koszarach ułanskkich, przebudowan
na szpital i świetlicę żołnierską. Centralne Archiwum Wojskowe, sygn. I.371.1.342

szwoleżerskich. Noc przebiegła spokojnie,

ale rankiem 14 maja lotnictwo zbombardo-

wało zabudowania koszar ułańskich. Jedna

z bomb trafiła w kasyno podoficerskie, niszcząc meble i sprzęt kuchenny. Około piątej po południu rządowe oddziały pozostające w koszarach huzarskich przypuściły szturm na swoich sąsiadów, którego skutkiem było zdobycie koszar szwolezerskich, które pozostały w rękach wojsk rządowych

do następnego ranka, kiedy to zostały puszczone, ze względu na konieczność bezpośredniej obrony Belwederu's.

ednym ze skutków przewrotu majowego było usunięcie wspomnianego juz Szwadronu Przybocznego Prezydenta Rzeczypospolitej, który został wcielony 15 Przewrót majowy 1926, red. A. Adamczyk, Londyn-
Piotrków Trybunalski 2003, s. 177-181. w szeregi 1 Pułku Szwoleżerów jako drugi szwadron. Wobec powyższego faktu,

1 Dywizion Artylerii Konnej przejął budynk nr 27, 28, 34, 35, 123, wartownię orazp nr $27,28,34,35$, stajnin wcześniej byly miejscem zakwaterowani Szwadronu Przybocznego. Jednocześnie Dywizjon zdał do dyspozycji Ministerstwa Spraw Wojskowych budynki nr 29, 32, 37, 68 170. We wspomnianych budynkach zakwaterował się m.in. szwadron pionierów

2 Dywizji Kawalerii. Pomieszczenia zajmowane przez 1 i 2 baterię dywizjonu oraz stajnie i kuchnie były oceniane pod względem komfortu jako bardzo dobre. Gorsze warunk w postaci małych pomieszczeń, piętrowych łóżek i bliskości mieszkań podoficerskich połóżek i bliskości mieszkań podoficerskich po-
siadała 3 bateria i łączność. W tym samym roku 1 Dywizjon Artylerii Konnej oficjalnie uzyskał swojego patrona - generała Józefa Bema. Z tej okazji przy ul. Huzarskiej przed budynkiem nr 123 na podwójnym cokole ustawiono popiersie generała (il. 4). Autorem rzeźby był oficer dywizjonu - porucznik Boblan Ś Boh̀ Swiejick Wroku 1926 dokono także rozbiónkidrewnianego pawilonu znajdującego się ha terenie koszar kirasjerskich. Do rzutu i przekrojów rozbieranego pawilonu dołączono również mapkę, z której wyn ka, że w tamtym czasie Kanał Piaseczyński był nieuregulowany ${ }^{17}$ - rozlewał się w płytk zabagniony stawik o nierównym brzegu, o czym wspominał Adam Królikiewicz, wybitny polski jeździec oraz oficer 1 Pułku Szwoleżerów. To właśnie przez zimną kapiel wzwolezón. To wąie whan Jasiek. Wiezchowiec puszczany luzem po koszarach, wpewien grudniowy wieczór udał się na swoją ulubioną kąpiel, ale był już na tyle stary, że nie mógł wydostać się z zabagnionej wody. Rankiem został odnaleziony przez służbę stajenną, a pomimo najlepszej

6 P. Zarzycki, dz. cyt., s. 8-9. 17 CAW, sygn. I.371.1.342, Budynek 102a w Koszarach
Legenda: $80,81,82,83,84,85,92$ - stajuic

79, 86,87- budynki koszarowe

88- budynek st

90 - aresst

98, 99, 100, $101-$ - szopy

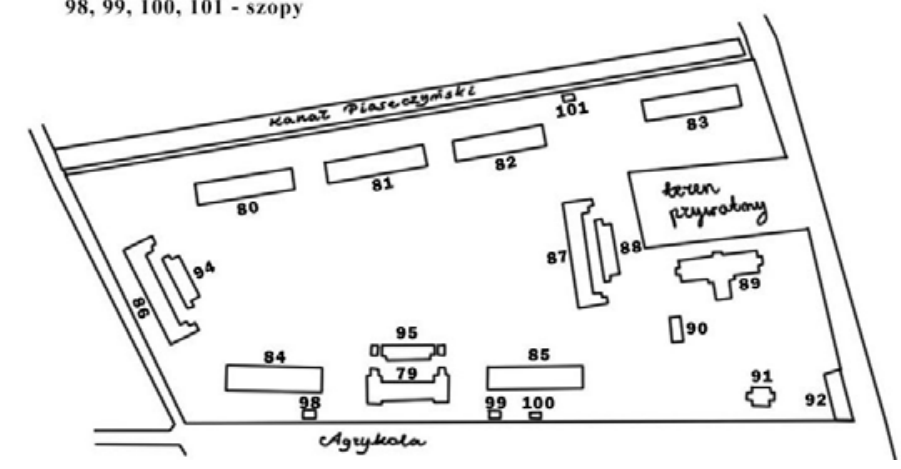

7. Plan Dużych Ułańskich Koszar w drugiej połowie

lat $30 \mathrm{XX}$ w. Oprac. W. Chrósny

Legenda:
1. - lazaret końs
2. magazyn
3,5 .

, 22, 23. budynki mieszkaln

6.
$7 \cdot$ piwniczka

7. piwniczka
$\mathbf{9}, 14,19$ - szopy

$11 \cdot$ kuźnia
$15 \cdot$ stajnia i

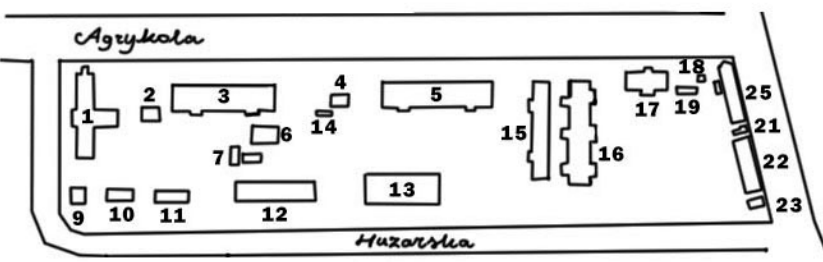

8. Plan Małych Ułańskich Koszar w drugie

połowie lat $30 \mathrm{XX}$ w. Oprac. W. Chrósny

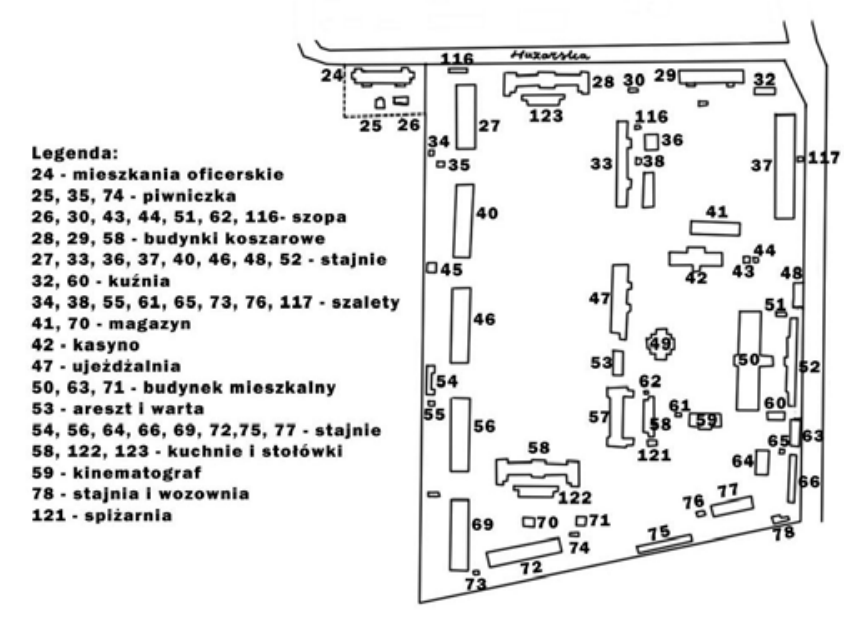

9. Plan koszar huzarskich w drugie

połowie lat $30 \mathrm{XX}$ w. Oprac. W. Chrósny 
opieki weterynaryjnej, zachorował na zapalenie płuc i padł 9 grudnia 1933 r..$^{18}$

W roku 1927 pomiędzy dowództwem Referatu Zarządzania Nieruchomościami D.O.K I a Marią Kozenas, właścicielką nieruchomości o numerze hipotecznym 3009 wcinającej się we wschodnią pierzeję zabudowań koszar ułańskich, trwały rozmowy o zamianie wspomnianego gruntu, który stanowił dość problematyczne sąsiedztwo. Najprawdopodobniej nie doszło do żadnego kompromisu, gdyż nieruchomość nr 3009 widnieje na zdjęciach lotniczych oraz mapach z drugiej polowylat 30 jako wydzielopach $z$ drugiej polowy lat 30 . Jako wydzielo-

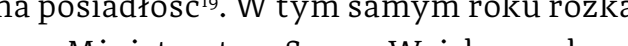
zem Ministerstwa Spraw Wojskowych nr 8 z dnia 3 marca 1927 r., koszary huzarsk zyskały nazwę Koszar im. Gen. Józefa
Bema, co było swoistym ukłonem w stro Bema, co było swoistym ukłonem w stronę
stacjonującego tam 1 Dywizjonu Artylerii stacjonującego tam 1 Dywizjonu Artylerii Konnej.

Rok 1928 przyniósł nowe prace w koszarach ułańskich. Przede wszystkim wybudowano nowe żelbetowe ogrodzenie kosza dowano nowe, żelbetowe ogrodzenie kosza od ul. Ułańskiej (Agrykoli), ciągnące się od Poza tym powzięto prace remontowe w buPoza tym powzięto prace remontowe w bu-
dynku nr 95 (kuchni z łaźnią), mające na celu dynku nr 95 (kuchni z łaźnią), mające na celu położenie instalacji elektrycznej oraz instalacji wodociągowej, wyburzenia niektórych szybów kominowych²

18 A. Królikiewicz, Olimpiiska szarża, Kraków 1992, s. 55. 19 CAW, sygn. I.371.1.1341, Plan sytuacyjny nieruchomości

20 CAW, sygn. I.371.1.342, Projekt parkanu żel.-betowego,

11 CAW, sygn. 1.371.1.1341, Projekt przebudowy budynku n - n g noleżerów im. J.P.

10. Artylerzysta konny skacze przez przeszkodę na terenie koszar $\mathrm{w}$ tle dawny murowany pawilon z pierwsze] połowy XIX w., rozebrany po 1945 Fot. N. Witczak-Witaczyński, Narodowe

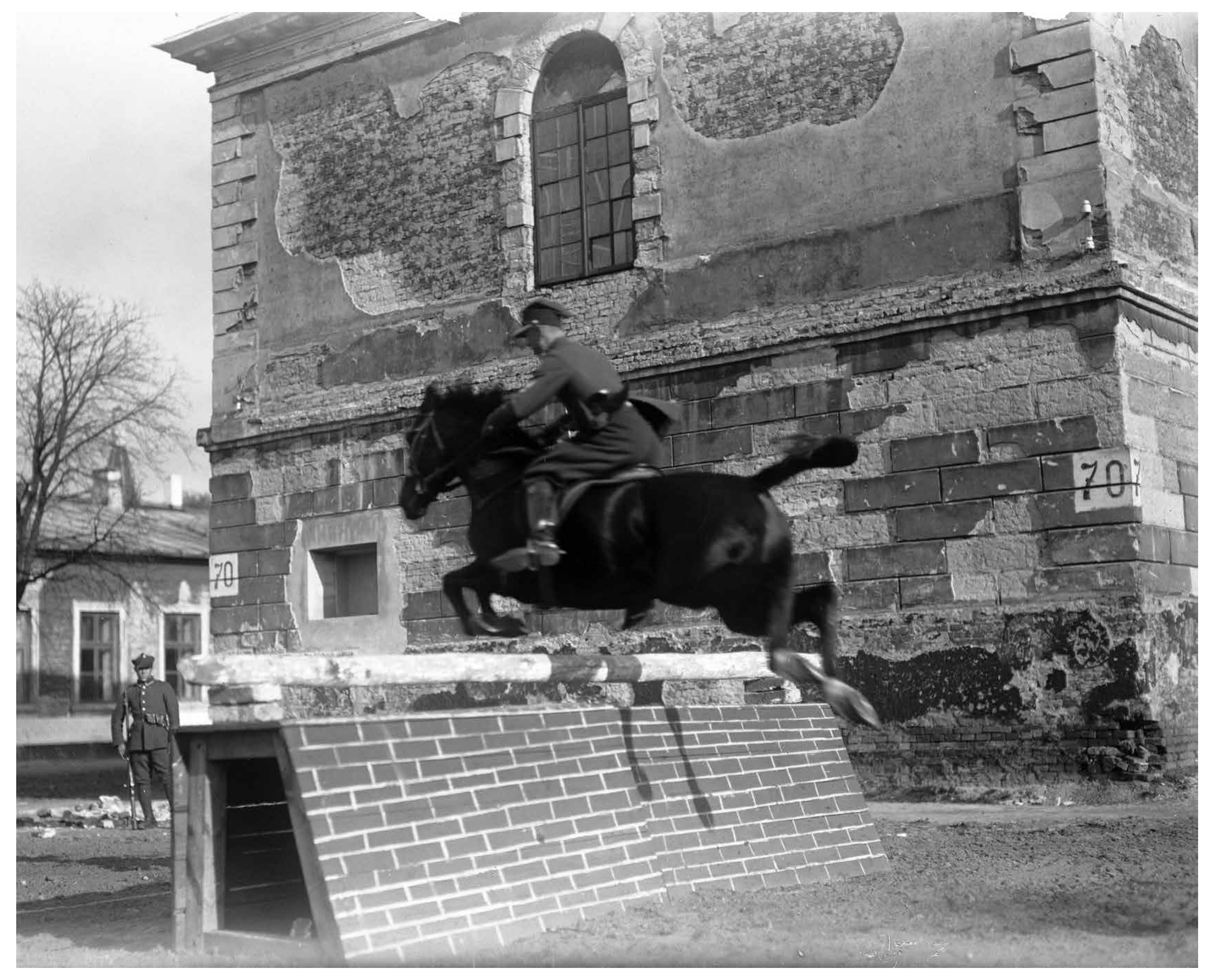


W 1930 r. dawny teren koszar kirasjerskich definitywnie stracił swoje kwaterunkowe funkcje, a na jego miejscu otwarto nowo wybuwany stadion należący do WKS Legia Warszawa. Tylko we wschodniej części dawnych koszar zachowało się kilka budynków uży tkowanych przez 1 Pułk Szwoleżerów. Pomysły na zagospodarowanie terenu dawnych koszar kirasjerskich pojawiały się już na początk lat 20. XX w., a w 1924 r. Ministerstwo Spraw Wojskowych przekazało na rzecz klubu WKS Legia subwencję w wysokości 70 ooo złotych, która miała być przeznaczo na na budowę nowego obiektu sportowego. Pomimo dofinansowania w roku 1925 i 192 nie przeprowadzono żadnych prac, co poskutkowało odebraniem praw Legii do administrowania terenem i groźbą zastąpienia przez konkurencyjną Lechię Warszaw Taki obrót spraw zmusił klub do podjęcia inicjatywy, do odzyskania praw, a przede wszystkim wymusił postępy w procesie projektowania stadionu. W roku 1927 Legi przedstawita projekt architektonicz Legia rozpoczęla budowę konpleksu sportow w skład którego wchodził stadion $\mathrm{z}$ boiskiem i trybunami na 6000 widzów, tor koarski, bieznia oraz basen. Budowa obiektów opóźniła się przez szalejący kryzys gospodarczy, ale ostatecznie w czerwcu 1930 r. otwarto basen, a w sierpniu tego samego roku stadion ${ }^{22}$.

W dostępnych archiwaliach zachowało się bardzo mało dokumentów świadczacych o remontach lub nowych budowlach z początku lat 3o. Wiadomo, że ok

1932 r. na terenie Małych Koszar Ułańskic wybudowano magazyn mobilizacyjny dla 1 Pułku Szwoleżerów ${ }^{23}$. Taki sam magazyn

22 Otwarcie nowego stadionu Legii Warszawa, http:// muzhp.pl/pl/e/1696/otwarcie-nowego-stadionu-le-

gii-warszawa [dostęp $8 \mathrm{~V}$ 2018]. 23 CAW, sygn. I.371.1.343, Rysunki wykonawcze magazy wystawiono w południowej części koszar huzarskich $^{24}$ (il. 5).

$$
\mathrm{Z} \text { dokumentacji pokontrolne }
$$

w 1 Dywizjonie Artylerii Konnej na rok 1933 możemy dowiedzieć się, że koszary huzarskie były utrzymane czysto i schludnie, pomimo nie najlepszego stanu zachowania. W złym stanie była m.in. sieć wodociągowa, a pęknięcia rur i wyciek wody spowodowały duże koszty naprawy. Dodatkowo dywizjon nie posiadał swojej własnej łaźni, w związku z czym kąpiele szeregowych odbywały się w łaźni 1 Pułku Szwoleżerów. Również możliwości magazynowe były niewystarczające i tylko miezy now by niewysta piętrzanie polek pozwalało na umieszczenie potrzebnych rzeczy. We wsponnianym okre-

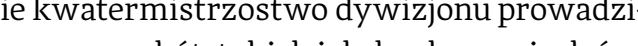
o szereg robót, takich jak: brukowanie dróg w obrębie koszar, budowę studni, budowę garażu i szopy na wozy oraz prace budowlane w kuchni żołnierskiej i prace wodno-kanalizacyjne w budynku mieszczącym dowództwo 3 baterię. Ponadto zakupiono drzewka, krzewy i nasiona do ogrodu. Duże kontrowersje wrasie kontroli wywolale krawabudowy wowej wartowni, do któcj to dowódca ppłk. ypl. Brzeszczynski ściągnął górali-budowniczych oraz materiał z Zakopanego. Budowa wartowni była przedmiotem rozmów pomiędzy ppłk. Brzeszczyńskim, a dowódcą Okręg Korpusu nr I, gen. Wróblewskim, który niestety nie posiadał środków na sfinansowanie przedsięwzięcia, w związku z czym dowódca dywizjonu postanowił rozwiązać sprawe we własnym zakresie. Wybudowanie wartowniwizyterki” było konieczne ze względu na wprowadzenie instrukcji o ochronie tajemnicy wojskowej, gdyż w koszarach huzarskich stacjonowały trzy różne oddziały, rodziny oficerskie i podoficerskie, a liczba interesantó i odwiedzających była na tyle duża, że wartownicy nie byli w stanie wszystkich kontrolować. Okazja do budowy nadarzyła się, gdy

24 CAW, sygn. I.371.1.343, Rysunki wykonawcze magazyn "mob" dla 1 d.a.k.
1Dywizjon Artylerii Konnej (dalej d.a.k.) powracał ze szkoły ognia w Czarnym Dunajcu. Budulec, robocizna, transport oraz strawne dla budowniczych-górali kalkulowabsię połowę taniej, niż gdyby roboty wykonywała firma warszawska, w związku z czym do stolicy wraz z dywizjonem powracającym transportem kolejowym, na lorach pomiędzy armatami i wozami przyjechał materiał, a osobnym pociągiem pracownicy, którzy zbudowali wartownię ${ }^{25}$.

Na terenie koszar huzarskich w roku 1933 odbyła się ważna uroczystość - piętnasta rocznica utworzenia artylerii konnej, w związku z czym postawiono tam pomnik Marszałka Józefa Piłsudskiego w formie dwóch cokołów połączonych poziomą beldwóch cokołów połączonych poziomą bel-
ką, pod którą stała armatka artyleryjka. Na bokach cokołów były wmontowane tablice z nazwami pól bitewnych, na których walczyli konni artylerzyści ${ }^{26}$

W roku 1932 lub 1933 powzietto prace budowlane przy budynku nr 87 (koszarowiec) oraz 88 (kuchnia) na terenie Dużych wiec) oraz sz (kuch. W kaszarowcu prowaKoszar Unáskich. W koszarowcuprowanowych pomieszczeń, zamurowanie niepotrzebnych otworów drzwiowych, wymian tynku oraz podłogi ${ }^{27}$. W zbiorach CAW zachował się jeden projekt bez daty, zakładający otynkowanie i obrukowanie budynku. Być może powyższe prace przeprowadzon także przy okazji remontu wewnątrz budowli ${ }^{28}$. Dawna kuchnia przeszła kapitalny remont, przy którym nadbudowano ją z przeznaczeniem na szpital i świetlice pułku. Budynek zyskał nową, modernipułku. Budynek zyskał nową, moderni-
styczną szatę architektoniczną. Prace przy styczną szatę architektoniczną. Prace prą
przebudowie skończyły się w roku 1934,

25 CAW, I.300.16.505. Korpus Kontrolerów, Kontrola w 1. Dywizjonie Artylerii Konne

26 P. Zarzycki, dz. cyt., s. 10

27 CAW, I.371.1.343, Plan I-piętra bud. 87 w Koszarach 1 p. szwoleżerów w Warszawie.

8 CAW, 1.371.1.343, Budynek nr 87 w 1 p. Szwoleżerów, a zostały wykonane przez Firmę Budowlaną inż. Podlecki Cz. Słobodziński W. i Ska ${ }^{29}$ (il. 6).

W 1936 r. przeprowadzono remont budynku nr 105, leżącego we wschodniej części dawnych koszar kirasjerskich. Na początku lat 20. w budynku znajdowała się kuźnia i kołodziejnia. Niestety nie wiadomo, czy wspomniany remont miał tylko poprawic warunki w budynku, czy miał za zadanie przystosowanie budowli do innych funkcji3i.

W związku z reorganizacją ilości dywizjonów artylerii konnej i rozwiązaniem 12 d.a.k, do 1 d.a.k.w 1937 r. trafiła jedna z baterii rozwiązywanego dywizjonu.

Wobec powyższego faktu na terenie koszar wybudowano nową działownię oraz wyremontowano jedną ze stajni ${ }^{31}$.

Pod koniec lat 30. ostatnie prace budowlane poświadczone przez zachowane dokumenty prowadzono w koszarach huzarskich w budynkach $n r$ 29, 57, 68, 50, przystosowanych wcześniej dla Batalionu Stołecznego", Wiązały się one m. in. z rozszerzeniem sieciwodociagowe;32. Przed wybuchen winy wyreglowano takic pobliski chan wojn wyregulowano takze pobliski Kanał Piaseczyński, wzmacniając brzegi oraz tworząc geometryczny zbiornik wodny na zachodnim krańcu, tuż pod skarpą z Zamkiem Ujazdowskim ${ }^{33}$. Plany koszar w drugiej połowie lat 30. przedstawione są na il. 7, $8 \mathrm{i} 9$.

\section{CAW, 1.371.1.343, Projekt szpitala i świetlicy}

1 p. szwoleżerów $w$ Warszawie.

30 CAW, sygn. I.371.1.343, Budynek nr 105 na terenie 1 p. szwoleżerów.

31 P. Zarzycki, dz. cyt., s. 8

2 CAW, sygn. I.371.1.323, Rysunki wykonawcze robót wykonanych przez firmę W. Kruszynskil i Ska na ter stotecznego.

$33 \mathrm{~W}$ zbiorach CAW zachował się projekt regulacji na 2 pot. lat 30. Regulacia w zakresie przedstawionym na planie nie została wykonana, ale fakt prac prowadzonych przy kanale potwierdzają przedwojen- 
W sierpniu 1939 r. zarówno 1 d.a.k. jak i 1 p.szw. odbywały ćwiczenia na letnic manewrach w rejonie Łochowa. Pod koniec sierpnia obie jednostki zostały odwołane do Warszawy, aby przeprowadzić mobiliza cję. Działania mobilizacyjne przeszły bez większych przeszkód i kawalerzyści oraz konni artylerzyści wymaszerowali w rejo koncentracji całej Mazowieckiej Brygady Kawalerii, która jednoczyła również 7 Pułk Ułanów Lubelskich, 11 Pułk Ułanów Legionowych oraz 4 Pułk Strzelców Konnych Ziemi Łęczyckiej. Warszawskie koszary nie zostały zupełnie opuszczone, albowiem wszystkie pułki zostawiały pewną liczbe żołnierzy z zadaniem formowani np. szwadronów marszowych, które teoretycznie miały dołączać do głównych sił w trakcie walk. Ponadto w Koszarach Huzarskich ciągle stacjonował Batalion „Stołeczny”, który później obsadzał stanowiska obronne na północy Warszawy ${ }^{34}$. Niestety brakuje relacji, co dokładnie dzia sie na terenie koszar w dniach 1-19 wrześni, i informacji, czy zabudowaniazos uszkodzone w uszkodzone w czasie walk. Koszary kawaleryjskie odegrały istotną rolę po 19 września. Tego dnia do Warszawy szarżą kawaleryjską przebił się 14 Pułk Ułanów Jazłowieckich, będący w składzie Grupy Operacyjnej Kawalerii gen. Romana Abrahama. Szarża Jazłowieckich Ułanów sparaliżowała planowane uderzenie niemieckie na główne siły Grupy Kawalerii gen Abrahama, przez co w nocy z 19 na gen. w whed Grupy weszty do Stolicy i podwuw sklad Grupy weszly do stolicy i po dwudniowym popasie na terenie Centralnego Instytutu Wychowania Fizycznego cała kawaleria została skierowana w rejon Łazienek, gdzie dokonano reorganizacji pułków. Zarówno konie, jak i żołnierze znaleźli schronienie w zabudowaniach kosza kawalerii i artylerii konnej, a rannych przeniesiono do pobliskiego Szpitala

Ujazdowskiego ${ }^{35}$. Po ogłoszeniu kapitulacji kawalerzyści rozpoczęli niszczenie i ukrywanie broni, której nie chcieli zdać Niemcom. Duże ilości różnego rodzaju Niemcom. Duże ilości różnego rodzaju zbrojenia zakopywano na terenie parku tazienkowskiego, a w gęste krzaki wprowadzano armatki przeciwpancerne, o czym wspominał Stanisław Grzesiuk ${ }^{36}$. Pod koniec września polskie pułki opuściły koszary, udając się do niewoli. Dowództwo Armi Niemieckiej przeznaczyło dawne koszary polskich kawalerzystów i artylerzystów konnych na kwatery dla 10 Pułku konnych na

W roku 1944, w obliczu wybuchu Powstania Warszawskiego dowództwo Armii Krajowej planowało uderzyć na koszary szwoleżerów zajęte przez Niemców. 1 sierpnia o godzinie „W” atak przypuści szwadron por. Aleksandra Tyszkiewicza ps. „Góral”. Natarcie wyszło z rejonu Stadionu Wojska Polskiego, ale wobec przeważajacych sił niescich, było całkowwie niacych sit nien " wyco by ą ze swicie nieudane. „Góral" wycofał się ze swoi pzrmi war stron przebicia się do Lasów Kabackich. Niestety oddział został zepchnięty na Sadybę, stracił jeden pluton i ostatecznie wrócił na Mokotów ${ }^{38}$. W drugiej połowie sierpnia koszary szwoleżerów były zajęte przez baon piechoty i baon Mongołów w służbie niemieckiej ${ }^{39}$. Wobec coraz bardziej skomplikowanej sytuacji i odcięcia Mokotowa

\footnotetext{
35 P. Rożdżestwieński, Ułani Jazłowieccy 1939, Warszawa 2007, s. 108.

36 S. Grzesiuk, Boso, ale w ostrogach, Warszawa 2018 s. 363.

37 „Wieczór Warszawski”, 4 XI 1939, nr 271, rok 12, s. 1, https://polona.pl/item/wieczor-warszawski-r-12-nr-271-5-pazdziernika-1939,OTEwNzA0/0/[dostęp

38 Powstanie na Mokotowie: relacje dowódców, red

39 Tamże, s. 120 .
}

powstańcze dowództwo planowało kolejny atak na koszary. Głównym efektem ataku miało być przełamanie pozycji nieprzyjaciela i połączenie Mokotowa ze

Śródmieściem. Natarcie wyszło w nocy z 27 na 28 sierpnia. Głównymi celami były pobliski klasztor nazaretanek, Stacja Pomp oraz koszary. Atak na dwa pierwsze obiekty doszedł do skutku, ale został wyhamowan poprzez silny ogień niemiecki z rejonu koszar. Powstańcy, którzy doszli pod mury zabudowań koszar huzarskich, również zostali zatrzymani przez zmasowany ogien nieprzyjacielski. Wobec braku powodzenia i dużych strat ppłk Leon Faleński ps. "Gryf"40 nakazał wycofanie się całości sił "Gryf " ${ }^{40}$ nakazał wycofanie się całości sił polskich na Gón ny Mokotów izaprzestanie akcji zaczepnejej ${ }^{4}$. Ataków nie ponawiano, natomiast Niemcy rozpoczęli bombardowanie Mokotowa, które spowodowało wielkie zniszczenia w zabudowaniach. Zarówno walki w czasie Powstania, jak i późniejsze w trakcie ofensywy Armii Czerwonej doprowadziły do znacznego zniszczenia koszar kawalery nicze z roku 1945, mozna zobaczyc, ż na nicze z roku rg4s mozna zobaczye, ze na terenie koszar ułanskich zostały doszczętnie zniszczone cztery stajnie, najstarsza stajnia z początku XIX w., ujeżdżalnia, jede budynek koszarowy, lazaret weterynaryjn oraz kasyno oficerskie. Pozostałe budynki zostały mocno ostrzelane, a wskutek pożarów wypalona została więźba i połacie dachowe. $\mathrm{W}$ dobrym stanie zachowały się jedynie: magazyn mobilizacyjny, dawny szpital i świetlica szwoleżerska, kościół oraz budynek Funduszu Kwaterunku Wojskowego znajdujący się na terenie Małych Koszar Ułańskich. Więcej szczęścia miały koszary huzarskie - tutaj doszczętnie zniszczony został zaledwie jeden budynek koszarowy ${ }^{42}$. Reszta zabudowań wyszła

40 L. Bartelski, Mokotów 1944, Warszawa 1986, s. 608 41 Powstanie na Mokotowie..., dz. cyt., s. 85-87. 42 Zdjęcia lotnicze z $1945 \mathrm{r}$., http://www.map. z wojennej zawieruchy $\mathrm{w}$ dobrym stanie, przez co zostały zajęte przez Ludowe Wojsko Polskie. Koszary ułańskie były systematycznie rozbierane - do ponownego użytku odbudowano zaledwie jeden budynek mieszkalny oraz zaadaptowano zachowane budowle. Niepowetowaną stratą było rozebranie najstarszych pawilonów magazynowych z lat 20. XIX w. (il.1o), zachowanych w obydwu założeniach.

\section{THE HISTORY OF CAVALRY}

BARRACKS NEAR THE LAZIENKI

\section{PARK IN WARSAW IN THE YEARS}

\section{PARK-1945}

\section{WERONIKA CHRÓSN}

The article describes the history of cavalry barracks, located near the Royal Garden "Eazienki Warszawskie" in Warsaw in the years 1918-1939. The methodology used in the text, was based on an archival query, a library query analysis of cartographic materials and aerial photographs. The author showed the history of cavalry barracks in Warsaw in which 1 Cavalry Regiment and 1 Squadron of Horse Artillery were stationed, emphasizing all spatial transformations that took place in the barracks before World War II. The article is the first to describe in greater detail the history of these military buildings. um.warszawa.pl/mapaApp1/n 